УДК 378.147.091.33:81'243

\author{
Shyba Alona \\ Candidate of Pedagogical Sciences, Ph.D., Associate Professor \\ Department of English \\ Yuriy Fedkovych Chernivtsi National University \\ Chernivtsi, Ukraine \\ a.shyba@chnu.edu.ua
}

\title{
STUDENTS' SOCIOCULTURAL COMPETENCE FORMATION DURING EXTRA-CURRICULAR ACTIVITIES
}

\begin{abstract}
Sociocultural competence became an integral part of the process of foreign language teaching. Relevant knowledge of the culture and social realities of collocutors helps maintain contacts and promotes a successful interaction. The objective of the article is to further study the concept "students' sociocultural competence" as well as the ways of its formation during extra-curricular activities. To complete this task a number of methods were applied: theoretical - to survey, analyse the problem under study and empirical ones (observation, interview) to study the peculiarities of the academic process. Various factors that influence the formation of the competence were analyzed. The author also investigated the efficiency of S. Krashen's hypotheses (the acquisition-learning hypothesis, the monitor hypothesis, the input hypothesis, the natural order hypothesis, the affective filter hypothesis) in the process of foreign language and culture learning not only during in-class but also out-of-class activities. Special attention is paid to the affective factors which influence this process - self-esteem, inhibition, risk-taking, anxiety and motivation. The author dwells upon the difference between intrinsic and extrinsic types of motives, and upon the importance of an integrative type as compared to an instrumental type of motivation in the process of sociocultural competence formation. Different examples of individual, group ad mass extra-curricular activities conducted at the Department of English aiming at fostering students' communicative competence are provided. The author came to the conclusion that extra-curricular activities, together with in-class work, stimulate the formation of students' sociocultural competence and make the process of foreign language learning more natural.
\end{abstract}

Key words: sociocultural competence, curriculum, extra-curricular activities, affective factors, motivation.

Introduction. Foreign language learning aims at the formation of students' communicative competence that is at the ability to use the language appropriately in order to achieve communicative goals in a given context taking into account certain cultural norms. Special attention should be paid to sociocultural competence, as it's impossible to conduct effective communication without sufficient knowledge of social realia and cultural peculiarities of other nations. Students acquaint new knowledge both during in-class and out-of-class activities. Involvement into extra-curricular work makes the process of language learning more interesting and motivating.

Analysis of recent research and publications on the problem under consideration. The role of sociocultural competence formation is grounded in the works of such researchers as I.Bim, R.Pavliuk, V.Safonova, G.Tomahin, M.Byram, M.Canal, A.Hadley. The works of O.Dobra, O.Kasachiner, V.Nikitenko, E.G.Whipple contribute to the study of extra-curricular activities on the efficiency of foreign language learning. Still the question of sociocultural competence formation via extra-curricular activities needs further investigations.

The aim of the given paper is to study the role of extra-curricular activities in the process of sociocultural competence formation. The task of the article is to further study the notion "sociocultural competence"; to analyse the factors that promote foreign language learning; to ground the significance of extra-curricular activities both in increasing students' motivation while foreign language learning and in sociocultural competence formation.

Methods used: to conduct the research a number of methods have been used: theoretical - to survey, analyse and summarise publications on the problem under study and empirical methods - observation and interview.

Discussion. Sociocultural competence has been under study of a number of scientists. And though there's no unanimity among authors in defining the term, they all agree, that it's an important part of the communicative competence. Celce-Murcia presented communicative competence in a form of a pyramid (1995) with the following components: linguistic, actional, discourse, strategic and sociocultural competence at the top. Sociocultural competence, according to the methodologist, refers to the speaker's pragmatic knowledge, i.e. how to express messages appropriately within the overall social and cultural context of communication. It comprises social contextual factors, stylistic appropriateness factors, cultural and non-verbal communicative factors [2].

Sociocultural aspect of future teachers' training is of especially great importance. "To study language without studying the culture of native speakers of the language is a lifeless endeavor" [3, p.144]. Understanding other people's lifestyle, customs and traditions should be done inseparably from language learning, as it helps both make learning more motivating and communication more effective.

A Lithuanian teacher and scientist Anužienè [1] stresses the importance of sociocultural conditions in the process of language learning. Besides, learning material should include data concerning social, economic spheres of the country, in other words should reflect the current cultural state as well as social factors.

Sociocultural competence contributes to the teacher's professional development. This should be kept in mind while planning the academic process and choosing the material to be taught. Studies show that formation of sociocultural competence may provide additional benefit, where it has been integrated into the general course of communication, so the formation of this competence should be included into general curriculum [8, p. 279].

Foreign language acquisition is a lengthy and rather a challenging process. It requires much time and effort on the behalf of both teacher and student. To make this process more predictable and successful teachers rely on the curriculum. It helps them design the teaching/learning process, defining the planned outcomes, choosing the materials to be taught in order to reach the goals, and deciding on the ways how to teach.

Designing the curriculum teacher should first have a clear understanding of the expected outcomes, it can help him/her select the materials, choose the approach, method and techniques appropriate to achieve the goals set. Writing about the main principles of designing the curriculum of second language teacher education, Graves 
states that it's essential to focus on "who and what will be taught, how it will be taught and learned" [6, p. 115].

As students study not only during their in-class activities, much attention should also be paid to outof-class activities, which appear to be a crucial factor in a natural acquisition of a foreign language. Extracurricular activities are student experiences that are not included in the educational curriculum and are conducted under teachers' guidance. They should be treated as a significant part of education, because it has been proved that extracurricular activities are as necessary as regular classes for development of skills. Furthermore, Tenhouse adds that extra-curricular activities are good opportunities for students to achieve their curricular goals. Students discover and develop their skills through these activities for achievement. Thus, the main task of extra-curricular work is deepening the knowledge gained by students during the learning process and applying it to practice; extending their general outlook [9].

It's important to organize the academic process for the prospective teachers in the way, when both in-class and extra-curricular activities help realize the main aims of TEFL. While planning the principles of a backward curriculum design should be observed, when students' outcomes and needs are of a prior concern. This helps make the learning process more natural, creating favorable conditions for language acquisition, rather that learning.

Trying to find the answer to the question how to organize the process of a foreign language learning effectively, so that sociocultural competence is naturally fostered, we addressed the research of a prominent American scientist Stephen Krashen [7], specializing in second language acquisition. His theory is based on five hypotheses: the acquisition-learning hypothesis, the monitor hypothesis, the input hypothesis, the natural order hypothesis, the affective filter hypothesis. Having analysed them we came to the conclusion that for sociocultural competence formation during extracurricular work, the acquisition-learning and affective filter hypotheses are of a prior importance, as they create favorable conditions for natural acquisition of the language and culture, also helping motivate students.

Teaching a foreign language, we should distinguish between learning and acquiring the language. Learning is a conscious process which results in conscious knowledge about the language, the student spends a lot of time in the classroom or out of it, learning grammar rules and long lists of new words. Krashen [7] believes it to be less effective than acquisition, which is, on the contrary, a subconscious process, that results in a natural acquisition of a second language. It is very similar to the way a child acquires his/her mother tongue. Explicit teaching of rules should be substituted be a natural meaningful interaction, which is easy to do during extracurricular work.

Affective factors are of a big concern in the process of foreign language teaching and learning too. The most important personality factors that contribute to the success of foreign language acquisition, according to Krashen, are self-esteem, inhibition, risk-taking, anxiety and motivation [7].

Personal's self-esteem is important in all aspects of human life, not only in study. Any cognitive activity can hardly be carried out successfully without some degree of self-confidence. And though it is hard to say whether self-esteem influences success in language learning or vice versa, the connection between them, as well as the importance to work on both is evident.

Anxiety and inhibition can also be typical in FLL as it's natural for a person to feel self-doubt or worry in a new situation or to build a "defense wall" against something unfamiliar. Excessive anxiety, as well as inhibiting learning hamper the process of language acquisition. Our observations proved that students' participation in extra-curricular activities helps lower their anxiety and inhibition which they display during in-class activities

Inhibition is closely connected with risk-taking. Foreign language learning, especially at the beginning, is almost impossible without making mistakes, and students should not fear making them but rather take risk and speak, which is the only way to make progress in FLL. Students with a high self-esteem are more eager to take risk in the academic process.

All above-said makes it possible to conclude that the affective factors are interrelated and influence the process of foreign language learning and that of the sociocultural competence development. Natural and friendly interactive language learning atmosphere during in- and out-of-class activities creates favorable conditions to raise students' self-esteem, risk-taking, lower anxiety and inhibition. Extra-curricular activities motivate students and encourage them to accept responsibility for their own learning and that of others.

Motivation deserves special attention, as it is the first crucial step in the process of language learning. Motivation is related to one of the basic aspects of the human mind and behavior. It determines the direction and magnitude of human behavior or, in other words, the choice of a particular action, the persistence with it, and the effort expended on it [4].

Gardner singles out four aspects of motivation: a goal, effortful behavior, a desire to attain the goal and favorable attitudes toward the activity in question [5]. The goal of the learner determines the type of motivation. Two most general types of motivation are intrinsic and extrinsic ones. If the goal of the learner is to study in order to get a positive grade or to please the parents, or to improve one's career, then it means that extrinsic type prevails. Intrinsic type of motivation is revealed when the student is stimulated to learn by his desire to improve his knowledge, to be a well-educated person. The teachers agree that students' success in study is higher when an intrinsic type of motivation dominates.

When speaking about motivation for the second language acquisition, two more types should be mentioned: integrative and instrumental. The integrative motivation means that students learn the language because they are eager to integrate into other community, where the target language is spoken. They are interested not only in the language, but in the culture of the people who speak that language. Students with instrumental motivation are driven by more practical reasons, like a possibility to study abroad, or to successfully pass the exam, etc. Thus, we use extra-curricular activities to stipulate students' intrinsic integrative motivation in foreign language learning.

Nowadays foreign language learning in class receives much attention, but extra-curricular activities are also important for the academic process. Being involved in different extra-curricular work students acquire foreign language easier, the learning process becomes more captivating and motivating. This activities help students learn the language and at the same time reveal their talents while acting, reciting, singing and playing. They are rather motivating for students who are participating in debates, dramas, they give students a good chance to express themselves freely. Various interest clubs develop students' speaking and writing skills, the participants learn how to cooperate and coordinate in different situations. Extra-curricular activities give possibilities for students to show themselves, to socialize, selfidentify and self-assess. They perform a great educational 
role, developing individuals morale principles. But what's most important about extra-curricular activities is that it allows students acquire the language naturally, developing students' communicative competence and consequently their sociocultural competence.

Various types of extra-curricular activities help extend students' knowledge of cultural norms of other nations, learn their customs and traditions. Planning and organization of extra-curricular activities is closely related to the curriculum of future teachers' training. Thus, their topics and the aims usually correspond to the year program and the main goals of teaching a foreign language.

The following forms of extra-curricular activities are practiced at the faculty of foreign languages of Chernivtsi National University: individual, group and mass work. Individual work presupposes that the student prepares a project on a certain topic suggested by the teacher. It is later presented to the whole group, discussed and assessed. The tasks for the individual extra-curricular work were: "Comparative analysis of life of youth in Ukraine and England", "Study the gender aspect in students' FL communicative competence formation", "Influence of the increasing tourists' interest to your native city on people's desire to learn foreign languages", "Influence of the visa-free regime in Ukraine on people's wish to study foreign languages", "Life of prominent people who lived and worked in Chernivtsi during Austrian / Romanian period".

As to the activities of the second type, students studying the foreign language can be organized in groups according to their interests and hobbies, they work on a systematic basis. These can be drama clubs, literature and art clubs, reading and translation hobby groups, etc. English speaking clubs, organized by Peace Corp volunteers are very popular at the department of English. Students are engaged in active language acquisition in an informal atmosphere, debating on different topics, watching and discussing various movies in English. There's also Baltic Studies Center, which organizes sociocultural seminars for students, interested in the Lithuanian culture.

Mass extra-curricular activities don't happen regularly, they are organized sporadically. To them belong various contests, competitions, conferences, festivals or cultural events dedicated to the study of another country's traditions, study of writers and poets and other prominent people of other countries. Lately at the department of English such mass extra-curricular activities as staging Shakespeare's plays; staging Arthur Conan Doyle's works; translation contest of Shakespeare's sonnets; spelling Bee contest; round table discussion "Restoration of Lithuania's independence: 100-th anniversary" were organized.

Conclusions. Extra-curricular activities help develop students' fluency in English, paying special attention to their sociocultural competence and teaching them to be tolerant to other cultures and traditions. They create favorable conditions for students' positive attitude to learning, motivating them and make a good platform for increasing their self-esteem. So, we plan to continue investigations in this sphere and study sociocultural competence formations at language camps and language summer schools.

\section{References}

1. Anužienė, I. (2015). Socio-cultural competence (self) development. Vocational training: research and realities, 26(1). Retrieved from www.degruyter.com/view/j/vtrr.2015.26.issue-1/vtrr-2015-0006/vtrr-2015-0006.xml. Web. 22 February 2018

2. Celce-Murcia, M., Dornyei, Z., \& Thurrell, S. (1995). Communicative Competence: A pedagogically motivated model with content specifications. Issues in applied linguistics, 6(2), P.11.

3. Crawford-Lange, L.M., \& Lange, D.L. (1987). Doing the unthinkable in the second-language classroom: A process for integration of language and culture. In Teaching for proficiency, the organizing principle. Lincolnwood, IL: National Textbook Company.

4. Dornyei, Z. (2001). Motivational strategies in the language classroom, London: Cambridge University Press

5. Gardner, R.C. (1985). Social psychology and second language learning: the role of attitudes and motivation, London: Edward Arnold (Publishers) Ltd.

6. Graves, K. (2009). The Curriculum of Second Language Teacher Education. In Burns, A., \& Richards, J.C. (Ed.). The Cambridge Guide to Second Language teacher education (pp. 115-124). London: Cambridge University Press

7. Krashen, S.D. (1981). Second language acquisition and second language learning, Califirnia: Pergamon Press Inc.

8. Mak, A.S., \& Buckingham, K. (2007). Beyond communication courses: Are there benefits in adding skills-based EXCELLTM sociocultural training? International Journal of Intercultural Relations, 31(3), p.279

9. Tenhouse, A. College extracurricular activities - Impact on students, types of extracurricular activities. In Encyclopedia of education. Retrieved from www.education.stateuniversity.com/pages/1855/College-Extracurricular-Activities.html. Web. 20 January 2018

\section{Список використаної літератури}

1. Anužienė I. Socio-cultural competence (self) development [Electronic resource] / Ieva Anužienė // Vocational training: research and realities. - 2015. - Vol.26, No. 1. - URL: https://www.degruyter.com/view/j/vtrr.2015.26.issue-1/vtrr-2015-0006/vtrr2015-0006.xml

2. Celce-Murcia M. Communicative Competence: A pedagogically motivated model with content specifications./ Marianne Celce-Murcia, Zoltan Dornyei, Sarah Thurrell // Issues in applied linguistics. - 1995. - № 6 (2). - P. 11

3. Crawford-Lange L.M. Doing the unthinkable in the second-language classroom: A process for integration of language and culture / L.M.Crawford-Lange, D.L.Lange // Teaching for proficiency, the organizing principle - Lincolnwood, IL: National Textbook Company, 1987. - PP.139-178.

4. Dornyei Z. Motivational strategies in the language classroom / Zoltan Dornyei. - N. Y.: Cambridge University Press, 2001. $155 \mathrm{p}$.

5. Gardner, R.C. Social psychology and second language learning: the role of attitudes and motivation / R.C.Gardner. - London.: Edward Arnold (Publishers) Ltd., 1985. - 208 p.

6. Graves K. The Curriculum of Second Language Teacher Education / Kathleen Graves // The Cambridge Guide to Second Language teacher education. - Cambridge University Press, 2009. - PP.115-124.

7. Krashen S. D. Second language acquisition and second language learning / Stephen D. Krashen. - California: Pergamon Press Inc, 1981. - $150 \mathrm{p}$.

8. Mak A. S., Buckingham K. Beyond communication courses: Are there benefits in adding skills-based EXCELLTM sociocultural training? / Anita S.Mak, Kirsten Buckingham // International Journal of Intercultural Relations. - 2007. - 31(3). - P.279

9. Tenhouse A. College extracurricular activities - Impact on students, types of extracurricular activities [Electronic resource] / A. Tenhouse // Encyclopedia of education. - URL: www.education.stateuniversity.com/pages/1855/College-ExtracurricularActivities.html 
Стаття надійшла до редакції 14.04.2018 р. Стаття прийнята до друку 19.04.2018 р.

\author{
Шиба Алёна \\ кандидат педагогических наук, доцент \\ кафедра английского языка \\ Черновицкий национальный университет имени Юрия Федьковича \\ г.Черновцы, Украина
}

\title{
ФОРМИРОВАНИЕ СОЦИОКУЛЬТУРНОЙ КОМПЕТЕНТНОСТИ СТУДЕНТОВ ВО ВРЕМЯ ВНЕКЛАССНОЙ ДЕЯТЕЛЬНОСТИ
}

Аннотация. Социокультурная компетентность является неотъемлемой составляющей процесса обучения иностранному языку, так как способствует общению между представителями разных национальностей. Целью этой статьи является исследование понятия «социокультурная компетентность студентов», а также способы ее формирования во время внеклассной деятельности. Для достижения поставленной цели был использован ряд теоретических (обзор и анализ литературы) и эмпирических методов (педагогической наблюдение и интервьюирование). Автор анализирует эффективность гипотез Стивена Крашена во время освоения иностранного языка на внеклассных мероприятиях, рассматриваются аффективные факторы, который влияют на процесс изучения иностранного языка. Приводятся образцы различных типов внеклассной работы студентов. Автор приходит к выводу о важности внеклассной деятельности студентов в процессе изучения иностранного языка и их эффективности в формировании социокультурной компетентности.

Ключевые слова: социокультурная компетентность, учебная программа, внеклассная деятельность, аффективные факторы, мотивация.

\author{
Шиба Альона Василівна \\ кандидат педагогічних наук, доцент \\ кафедра англійської мови \\ Чернівецький національний університет імені Юрія Фельковича \\ м. Чернівці, Україна

\section{ФОРМУВАННЯ СОЦІОКУЛЬТУРНОЇ КОМПЕТЕНТНОСТІ СТУДЕНТІВ ПІД ЧАС ПОЗАКЛАСНОЇ ДІЯЛЬНОСТІ}

Анотація. Соціокультурна компетентність є невід'ємною складовою процесу навчання іноземної мови, оскільки вона сприяє спілкуванню між представниками різних національностей. Метою даної статті $\epsilon$ дослідження поняття «соціокультурна компетентність студентів» та шляхи її формування під час позакласної діяльності. Для досягнення поставленої мети було використано ряд теоретичних (огляд та аналіз літератури за темою дослідження) та емпіричних методів (педагогічне спостереження та інтерв'ювання). Автор аналізує ефективність гіпотез Стівена Крашена під час освоєння іноземної мови на позакласних заходах, розглядаються афективні фактори, які впливають на процес вивчення іноземної мови. Наводяться зразки різних типів позакласної роботи студентів. Автор приходить до висновку про важливість позакласної діяльності студентів у процесі вивчення іноземної мови та їх ефективність у формуванні соціокультурної компетентності.

Ключові слова: соціокультурна компетентність, навчальна програма, позакласна діяльність, афективні фактори, мотивація. 